\title{
Online Distance Learning While the COVID-19 Pandemic: Implementation, Evaluation, and Expectations
}

\author{
Syahrul Ramadhan ${ }^{1, *}$ Elfia Sukma ${ }^{1}$ Vivi Indriyani ${ }^{1}$
}

\author{
${ }^{1}$ Indonesian Language Department, Universitas Negeri Padang, Padang, Indonesia \\ *Corresponding author. Email: syahrul_r@fbs.unp.ac.id
}

\begin{abstract}
In 2020, the COVID-19 pandemic occurred almost and spread to various people in the world. To protect the lives and health of the people, the government has organized various forces to prevent one of them by taking policies in education by implementing distance education. This study will explain the application of distance learning in language learning and teacher evaluation and expectations for improving education in next semester's learning activities. This research is a descriptive study using a survey method. The participants in this study were Indonesian Language teachers at the secondary school level in West Sumatra. The sample of this study were 108 teachers. In this study, questionnaires were distributed to all secondary teachers in West Sumatra through whatsApp media by distributing questionnaire links created using the Google form application. The instrument used was a questionnaire in the form of a questionnaire consisting of thirty-six statements. Based on the results and discussion it can be concluded that online distance learning during the COVID-19 pandemic has been carried out in almost all regions of West Sumatra in accordance with government policy. Even though it has been implemented well, but the implementation of this learning still has limitations so it needs to be further improved so that learning can be implemented better.
\end{abstract}

Keywords: online learning, distance learning, covid-19, learning activities.

\section{INTRODUCTION}

At the end of 2019, the COVID-19 pandemic broke out in Wuhan, China with a rapid and dangerous spread that spread to various people in the world. The novel Coronavirus known as COVID-19 (or SARS-CoV-2 in the medical community) takes deadly tolls worldwide [1]. To protect people's lives and health, the government has organized various forces to prevent and control them, and adopt various measures to prevent the spread of a large-scale pandemic. One of the steps pursued by various countries is in the field of education [2]. Assurance of kids and instructive offices is vital. Safeguards are expected to forestall the likely spread of COVID-19 in the school area. The education environment must remain friendly, respectful, inclusive and supportive of all people. Steps taken by schools can forestall the passage and spread of COVID-19 by understudies and staff who might have been presented to the infection, while limiting disturbance and securing understudies and staff [3].
To prevent the spread of pandemics to schools and reduce the impact of pandemics, one of the affected countries, namely China, has issued a notice through the Chinese Ministry of Education, which requires schools of all types to postpone the spring semester of 2020 and encourage the provision of guidance services for learning at home students via the Internet [2][4][5]. The policy is termed "School Out, But Class On" which is "suspending classes without stopping learning", to provide online tutoring for students at home [2][6]. Teachers and students no longer meet each other as usual. Regardless of whether they want to or not, teachers must quickly adapt to changes in this teaching method and replace the accompanying roles[6].

Similar to the governments of countries affected by the pandemic, in Indonesia also made various efforts to prevent the COVID-19 virus. President Joko Widodo, as reported by CNBC Indonesia.com, issued a policy of Large-Scale Social Restrictions (PSBB) to suppress the spread of the corona virus. The decision was written in Government Regulation Government Regulation Number 21 Year 2020 concerning PSBB in the 
Framework of Accelerating Handling of Covid-19 [7]. Restrictions imposed by the government have an impact on the routine of the whole community, including students in Indonesia. At a global level, changes in learning due to the spread of the COVID-19 virus also took place very quickly. Based on UNESCO data, on March 12 there were only 29 countries implementing a policy to close schools. On March 18, that number had grown to 112 countries. Of the 112 countries, 101 countries implemented national school holidays. While 11 other countries, including Indonesia, implement school holidays in certain regions [8].

The Ministry of Education and Culture (Kemdikbud), Nadiem Makarim, on the date of March 12, 2020, published two circular letters relating to the prevention and treatment of COVID-19. First, circular No. 2 of 2020 concerning Prevention and Handling of COVID-19 within the Ministry of Education and Culture. Second, circular No. 3 of 2020 concerning Prevention of COVID-19 in the Education Unit which contains guidance on steps to prevent the spread of Covid-19 within the education unit [8]. Subsequently, followed by Circular of Minister of Education and Culture No. 4 of 2020 concerning Implementation of Education Policy in the Emergency Period of the Spread of COVID-19. The physical and mental health of students, teachers, school principals and all school residents is a major consideration in stopping education activities in schools [9]. Responding to the policy of learning from home, the Ministry of Education and Culture also negates the National Examination for this year [10][11].

Indonesian education applies "School From Home" for the implementation of learning activities at the time of COVID-19 prevention. "School From Home" is a method of Distance Learning conducted by teachers and students using electronic media as a communication tool [12]. Some educational institutions in certain areas affected by COVID-19 have begun implementing distance learning systems in order to minimize the speed of COVID-19 in some areas [13]. Schools and teachers play an important role in the implementation of these activities and are expected to be able to provide the best service in the midst of a pandemic, by innovating distance learning models and designing varied and fun learning tasks (enjoy learning), so that the learning process at home is able to present enthusiasm and joy for students.

The steps adopted by the Ministry of Education and Culture to support the activities of the School From
Home are as follows. First, develop a distance learning application based on portal and Android, which is "Rumah Belajar". Second, working with various parties to support online learning. Some parties that focus on developing online education systems include Google Indonesia, Smart Class, Microsoft, Quipper, Ruangguru, Sekolahmu, and Zenius [8]. Third, through the Ministry of SOEs, the government provides quota-free data access of up to $30 \mathrm{~GB}$ for students to access learning applications that have collaborated with Telkomsel. Among them the "Ruang Guru" and other applications that are incorporated in the Ilmupedia package such as Quipper, Zenius, Bahaso, and Cakap [13]. Fourth, the Minister of Education and Culture appreciates the proactive steps taken in all lines of local government and partners in the private sector to encourage online learning for students [11]. With the facilities provided, the government seeks to keep the learning process carried out.

Based on these problems, distance learning is one of the solutions used by various places in the world to overcome the pandemic of spreading COVID-19. The terms commonly used to describe this learning include: correspondence education, external studies, home study, independent study, distance teaching, independent teaching, continuing education, adult education, technology based or mediated education, student centered, open learning, e-learning, and online education [14].

Distance learning is not a new method, it has been around for hundreds of years starting in Europe [15][16]. This appears to meet the demands of increasing student numbers while also reducing costs and generating income to provide quality education [17][18]. The idea of learning is self-guided education which is more guided because teachers and students are are genuinely isolated and can serve countless objective gatherings immediately, and discover a way to interconnected information. [19]. Through this, access to educational opportunities can be increased regardless of the group of students who experience geographical challenges; flexibility in time and speed and students are free to choose their own learning environment [20].

Technological growth and student involvement in online learning have taken a new form [17Before, distance learning understudies could not associate openly with one another to share their experiences and interests. Nonetheless, new innovation joins understudies and helps construct a local area of students through distance schooling [21]. Endeavors to propel 
the opportunities for significant and intuitive distance learning keep on expanding. No doubt, web based learning openings will proceed to develop, and this should make new and creative instructional methods and advancements that help web based educating [22]. The internet, through its capacity to offer offbeat and coordinated exercises, has turned into an astounding stage for leading distance schooling through internet based talk and conversation meetings that can be utilized to draw in understudies in instructor and understudy communication, and connection between understudies [16][23]. Before the advent of Internet technology, distance education was mainly delivered via radio and television in addition to sending audio cassettes and by sending lessons by mail [15].

That makes distance learning an important element of the education system in the 21 st century. The importance of distance learning will increase in the near future to meet the rapidly changing learning needs of the community [24]. However, there are ambiguities and disagreements about what should be taught, the workload of teachers and students, how to teach, the teaching environment, and its implications for educational equity in the current pandemic of the spread of COVID-19. Possible difficulties encountered include: weaknesses in online teaching infrastructure, information gaps, lack of teacher experience, complex environment at home [25]. In addition, at the beginning of this implementation there was a delay, because everyone needed to ensure health to start learning properly, both physically and psychologically [26][27]. Based on that, this study will analyze the implementation, the constraints found and the expectation that there will be a distance learning that will be carried out in secondary schools in West Sumatra, Indonesia.

\section{METHOD}

This research is a descriptive study using a survey method [28]. Survey method is described as a research method that attempts to define cases as they are from research samples obtained from the study population. The study population consisted of Indonesian Language teachers in West Sumatra who taught at the secondary school level [29]. The sample of this study were 108 teachers. Respondent data for this study are as follows. First, the respondent is a teacher who teaches at the junior high school level (61.1\%), senior high school (31.5\%), vocational high school (7.4\%). Second, teachers are Bachelor graduates (56.6\%), Professionals
(2.8\%), and Masters $(40.7 \%)$. Third, teachers are male $(79.6 \%)$, and female $(40.1 \%)$. Fourth, teachers aged 2029 years $(30.6 \%), 30-39$ years $(38 \%), 40-49$ years $(14.8 \%)$, and more than 50 years (16.7\%). Fifth, teachers have been teaching for 1-5 years (31.5\%), 6-10 years $(22.2 \%), 11-15$ years $(19.4 \%), 16-20$ years $(8.3 \%)$ , more than 20 years $(18.5 \%)$. Sixth, teachers already have educator qualification certificates (55.6\%).

In this study, questionnaires were distributed to all secondary teachers in West Sumatra through media by distributing questionnaire links created using the Google form application. The instrument used was a questionnaire in the form of a questionnaire consisting of thirty whatsApp-six statements [30]. The instrument was used to find out the opinion of the correspondent regarding the implementation, the constraints found and the expectation that distance learning would take place at school.

\section{RESULT AND DISCUSSION}

The results of this study were obtained from the results of a questionnaire analysis filled out by the teacher. The results of this study are based on three things, namely the application of distance learning by schools; the application of online distance learning in Indonesian subjects; an evaluation of the online distance learning process that was carried out during the COVID-19 pandami. The results of the study, explained as follows.

Based on questionnaire data, in West Sumatra schools implemented online distance learning during the pandemic with a percentage of $99.1 \%$. The implementation of distance learning began with a variety of times, the most percentage showed that this learning was carried out on 20-23 March 2020 with 35 respondents who answered. With a percentage of $94.4 \%$ of respondents doing this learning from home. Internet network facilities / conditions to support this learning were found to be $5.6 \%$ (very supportive), $39.8 \%$ (supportive), 37\% (sufficiently supportive), and $16.7 \%$ (less supportive). During the pandemic, the government provided assistance for this online distance learning process, based on questionnaire data, only 50.9\% of teachers received the assistance, $17.6 \%$ (cash); $17.6 \%$ (pulses); 14.8 (data package); and 50\% (other forms). The cost that teachers use to support this learning for one month is $37 \%$ (> Rp. 100,000); $45.4 \%$ (Rp.100,000Rp.200,000); and 13\% (Rp.200,000-Rp.300,000). 
Furthermore, the readiness of teachers in online learning was found to be $10.2 \%$ (very ready), $33.3 \%$ (ready), $38.9 \%$ (quite ready), and $17.6 \%$ (less ready). $73.1 \%$ of teachers said that face-to-face learning was better than distance learning, $22.2 \%$ said that face-toface learning was the same as distance learning, and only a few said that distance learning was better than face-to-face learning, even though has been facilitated by online learning.

In addition to the implementation of learning in general and learning facilities, the data traced also about the process of learning Indonesian while online distance learning during the pandemic was enacted. The results of the study can be seen in table 1 .

TABLE I. IMPLEMENTATION OF ONLINE DISTANCE LEARNING IN LANGUAGE Classes

\begin{tabular}{|l|c|c|c|}
\hline \multicolumn{1}{|c|}{ Statement } & \multicolumn{2}{|c|}{ Answer (\%) } \\
\cline { 2 - 4 } & Yes & Maybe & No \\
\hline $\begin{array}{l}\text { The teacher is ready with electronic } \\
\text { devices for the online distance learning } \\
\text { process. }\end{array}$ & 72.2 & 16.7 & 11.1 \\
\hline $\begin{array}{l}\text { The process of teacher learning activities } \\
\text { is in accordance with the syllabus that has } \\
\text { been designed. }\end{array}$ & 43.3 & 13.9 & 42.6 \\
\hline $\begin{array}{l}\text { The process of teacher learning activities } \\
\text { in accordance with the planned time. }\end{array}$ & 28.7 & 12.0 & 59.3 \\
\hline $\begin{array}{l}\text { The teacher provides regular guidance and } \\
\text { delivery of material during the online } \\
\text { distance learning process. }\end{array}$ & 67.7 & 11.1 & 21.3 \\
\hline $\begin{array}{l}\text { The learning material designed is still } \\
\text { relevant to be used during the online } \\
\text { distance learning process. }\end{array}$ & 60.2 & 25.0 & 14.8 \\
\hline $\begin{array}{l}\text { The designed learning media is still } \\
\text { relevant to be used during the online } \\
\text { distance learning process. }\end{array}$ & 53.7 & 25.9 & 20.4 \\
\hline $\begin{array}{l}\text { The approach / method / learning strategy } \\
\text { designed is still relevant to be used during } \\
\text { the online distance learning process. }\end{array}$ & 43.5 & 28.7 & 27.8 \\
\hline $\begin{array}{l}\text { Evaluation of learning designed is still } \\
\text { relevant to use during the online distance } \\
\text { learning process. }\end{array}$ & 47.4 & 23.1 & 19.4 \\
\hline $\begin{array}{l}\text { There is feedback from the teacher } \\
\text { regarding the assignments given to } \\
\text { students. }\end{array}$ & 82.4 & 11.1 & 6.3 \\
\hline $\begin{array}{l}\text { The teacher provides an opportunity for } \\
\text { students to make improvements to the } \\
\text { assignment if it still does not meet the } \\
\text { expected competencies. }\end{array}$ & 90.7 & 5.6 & 3.7 \\
\hline
\end{tabular}

The hardware used by teachers to support online distance learning during the pandemic can be seen in the following figure 1 .

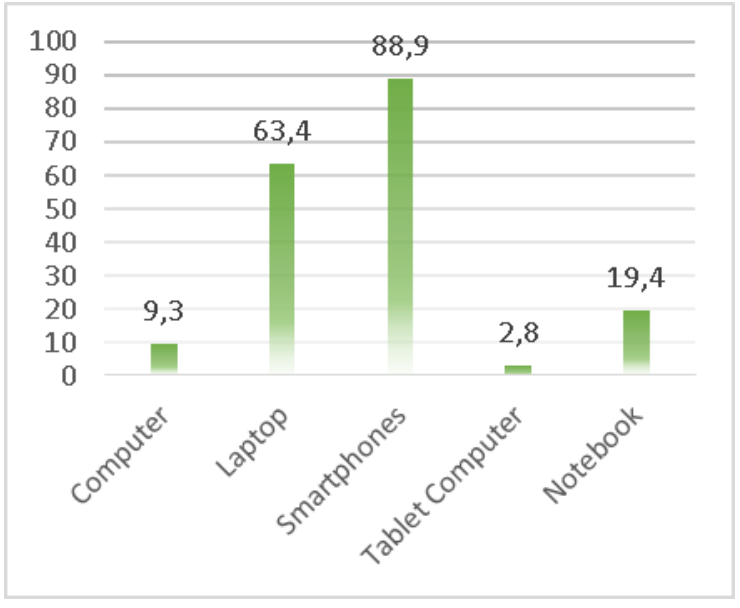

Fig. 1 Hardware used by teachers

Learning materials used by teachers to support online distance learning during a pandemic can be seen in the following figure 2 .

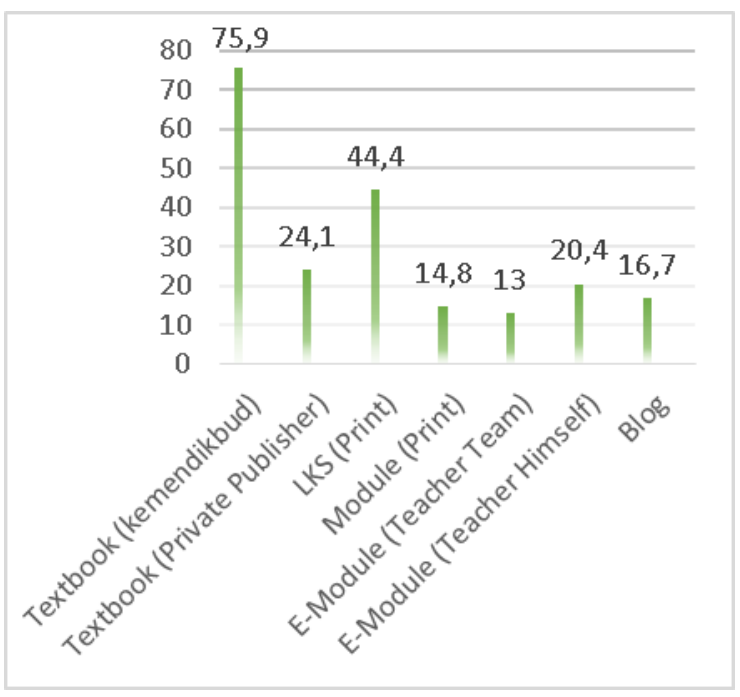

Fig 2. Learning materials used by teachers

The learning media that teachers use to support online distance learning during a pandemic can be seen in the following figure 3 . 


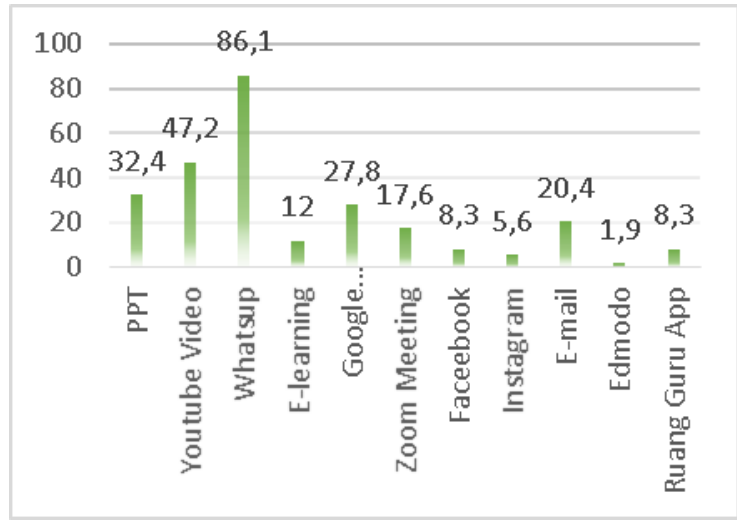

Fig. 3 The Learning media used by teachers

The approach/method/learning strategy used by teacher to support online distance learning during the pandemic can be seen in the following figure 4 .

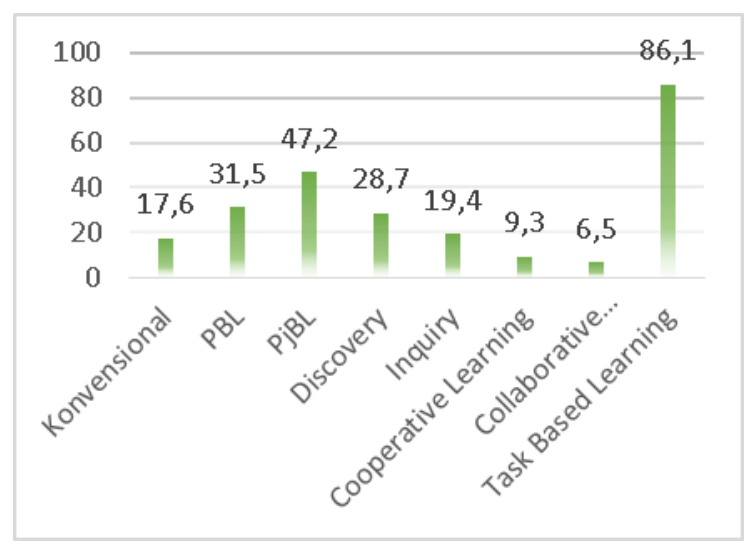

Fig. 4 The approach/method used by teachers

Learning evaluations that teachers use to support online distance learning during a pandemic can be seen in the following figure 5 .

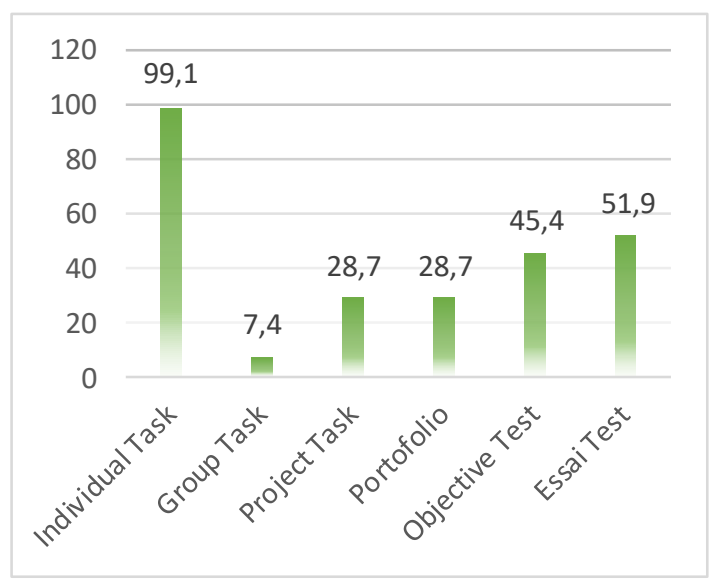

Fig. 5 Learning evaluation used by teachers
Based on the results of the questionnaire analysis, the competence of teachers and students when online distance learning during a pandemic can be seen in the following table 2 .

TABLE II. TEACHER COMPETENCIES IN ONLINE DISTANCE LEARNING

\begin{tabular}{|l|c|c|c|c|c|}
\hline \multirow{2}{*}{ Statement } & \multicolumn{5}{|c|}{ Answer (\%) } \\
\cline { 2 - 6 } & $\begin{array}{c}\text { Not } \\
\text { good }\end{array}$ & $\begin{array}{c}\text { Less } \\
\text { good }\end{array}$ & $\begin{array}{c}\text { Quite } \\
\text { good }\end{array}$ & Good & $\begin{array}{c}\text { Very } \\
\text { good }\end{array}$ \\
\hline $\begin{array}{l}\text { The level of student } \\
\text { understanding when online } \\
\text { distance learning. }\end{array}$ & 0.9 & 17.6 & 63.9 & 17,6 & 0.0 \\
\hline $\begin{array}{l}\text { Competence of delivering } \\
\text { distance learning material } \\
\text { online. }\end{array}$ & 0.9 & 6.5 & 50.9 & 39.8 & 1.9 \\
\hline $\begin{array}{l}\text { The quality of the } \\
\text { presentation of learning } \\
\text { material that the teacher is } \\
\text { doing (infographics, video, } \\
\text { animations, pictures, etc.) }\end{array}$ & 1.9 & 13.0 & 50.0 & 33.3 & 1.9 \\
\hline $\begin{array}{l}\text { Students are able to do the } \\
\text { assignments given by the } \\
\text { teacher correctly. }\end{array}$ & 1,9 & 7,4 & 23,1 & 52.8 & 14,8 \\
\hline $\begin{array}{l}\text { Students are able to do the } \\
\text { assignments given by the } \\
\text { teacher on time. }\end{array}$ & 7,4 & 19,4 & 28,7 & 33,3 & 11,1 \\
\hline
\end{tabular}

Based on data about online distance learning activities during the pandemic, we need to evaluate so that the learning process can be carried out better than it is today. That is because online distance learning is still being held for learning activities in the coming semester until a time that has not been ascertained so that learning can be done again as before, namely face to face learning. Data for the evaluation are obtained from a questionnaire filled out by the teacher which is described as follows.

First, the level of teacher satisfaction with online distance learning during the pandemic was $5.6 \%$ (very satisfied); $15.7 \%$ (satisfied); $45.4 \%$ (quite satisfied); $28.7 \%$ (less satisfied); and $4.6 \%$ (less satisfied). Second, according to the teacher, the advantages of online distance learning during the pandemic, which can be done anytime $(73.1 \%)$; can be done anywhere $(83.3 \%)$; flexible and relaxed $(63 \%)$; new experience $(75 \%)$; material documented and can be re-studied $(43.5 \%)$; time and cost efficient $(25.9 \%)$; innovative and varied learning (29.6\%); interesting and fun lessons (20.4\%); increase student interest in learning $(9.3 \%)$; increase learning motivation $(6.5 \%)$. Third, according to the teacher, the lack of online distance learning during the pandemic, namely the teacher's internet network is sometimes unstable $(63.9 \%)$; Student internet networks are sometimes unstable $(89.8 \%)$; excessive workload (31.5\%); students are less active and communicative 
(73.1\%); student assignments tend to be duplicated $(65.7 \%)$; requires a large fee $(56.5 \%)$; facilities not yet owned by all students (72.2\%); teacher's media and digital competency is low (37\%); students' media and digital competency is low $(49.1 \%)$; the material is difficult for teachers to explain and understand $(50 \%)$; difficult to monitor student competency levels $(67.7 \%)$. Fourth, disaster mitigation and response activities during the COVID 19 pandemic carried out by schools, among others; tracking the condition and position of teachers $(28.7 \%)$; provide assistance with the cost of internet conditions (38.9\%); provide additional intensive due to disasters $(9.3 \%)$; provide health services $(12 \%)$; provide psychological consulting services (3.7\%).

Teachers' expectations for online distance learning during the pandemic for new semester learning activities are as follows. First, the learning process is carried out again using the direct method or face to face. Secondly, there is a lack of curriculum for online distance learning. Third, increase the availability of learning facilities to support online distance learning. Fourth, provide facilities such as webinars on the implementation of online distance learning. Fifth, provide training to teachers to be able to improve competence in developing media and learning resources for the implementation of online distance learning. Sixth, there needs to be an evaluation of teachers in order to improve the quality of teaching during a pandemic.

Based on the results of the study, online distance learning at the time of the pandemic was almost 100\% implemented. The learning process is carried out from home based on recommendations from the government. That may be motivated by security [31]. Distance education during this pandemic can be carried out because of the support of technological devices, so learning can be done online. By utilizing information and communication technology, such as computers connected to the Internet, the learning process can be carried out [19][32]. In distance learning, technology can provide several benefits, namely technology gives broad access to students to access information, both in quality and quantity; technology can help students in managing and controlling the learning process; students can increase flexibility and comfort in learning [33]. It can also support the government's suggestion to implement this learning from home [34].

At present, technological barriers or lack of student access to the Internet are no longer a major challenge for distance education initiatives [35]. However, based on data, teachers and students have not evenly distributed the technology tools to support distance learning. Because in some developing countries, poor information technology infrastructure is still a challenge for implementing this learning [36]. The internet has always been a problem in most countries, because Internet access is not widely available and tends to be located in big cities rather than in rural areas [15][37]. That also includes in Indonesia, one of which is in the West Sumatra area, there are still some rural areas that have poor connections to the internet network, so this implementation is still constrained in several places.

In addition to technology, institutions also have an influence on the implementation of quality distance learning [38]. Based on the data, not all teachers have the financial support to carry out this distance learning. Because cost is one of the issues that can be a problem for online distance learning [39] during the COVID-19 pandemic.

Based on the analyzed questionnaire data, the learning process can be concluded as follows. First, mobile devices are more widely used for online distance learning. This is supported by data that there is an increase in sales of mobile devices, rapid advances in cellular technology and features and increased availability of various mobile applications [40] which allows students to have the opportunity to conduct learning activities using mobile devices [41]. These days, cell phones permit people to call, message, email, video conferencing, miniature web journals, collaborate on informal communities, surf the Internet, watch and offer recordings and pictures, play computer games and exploit different programming driven applications [42]. With easy accessibility and portability of cellular technology, learning activities such as training specifically in education can be done outside the classroom other than in the classroom [43]. Thus, the use of mobile devices is a good alternative to be used in the learning process [44][45].

Second, learning resources are still dominated by the use of printed books. This is very contradictory for supporting online distance learning. One of the obstacles is the teacher needs to plan in advance the source of learning for the learning process to be carried out [31]. However, this learning occurs suddenly so that the teacher does not have the preparation to develop digital learning resources. The teacher must prepare distance learning material among the workloads that seems to be another problem [39]. It was also found in previous studies, that developing self-learning resources 
by teachers still had several obstacles, the teacher was still at the user level, rather than being the developer of teaching materials to be used [46][47][48].

Third, whatsapp social media is more widely used than social network learning such as Edmodo. Social media is one factor that is very supportive for the implementation of online distance learning [49]. In the context of social networking, the distance learning setting permits limitless admittance to material that can be finished at a work level that is agreeable for people and the capacity for consistent gathering input [50]. Continuing use of social media such as Facebook, whatssup and Twitter as tools in education, has led to the proliferation of technology that is not necessarily designed for teaching and learning [51]. If this tool, which is commonly used in our daily lives, is not easy to use in education; or if they do not have an important function to enable learning, there will be no point in using it [52]. Based on that, social media specifically designed for learning such as e-learning, edmodo, and google classromm are more recommended for use in the learning process.

Fourth, more learning methods use Task Based Learning, following PBL, PjBL, Discovery, and Inquiry which are quite widely used. Whereas Cooperative Learning and Collaborative Learning are used less. Fifth, individual assignments are used more than group assignments and it is in line with the learning methods used. Distance learning is more individualized learning, so students can choose their own learning environment and be responsible for the speed of their learning [19]. This is supported by the use of learning methods used by teachers which are dominated by the use of learning methods which tend to be used for individual learning rather than group learning methods. In addition, it also relates to the evaluation used.

Based on the questionnaire data, the teacher's competence for online remote implementation tends to be good. This was also supported by previous research on the media and digital competence of language teachers in West Sumatra [53][54][55]. It is very supportive for the implementation of learning, so that language teachers can practice their competencies for the implementation of learning today. However, not all teachers have good competencies, so further training is needed to improve these competencies, so that the online distance learning process can be implemented well. With the method of delivering teaching and interaction through information technology, it is necessary that all parties involved in distance learning have information technology knowledge to get the maximum benefit in their use [33].

The teacher believes that face-to-face learning is better than distance learning. This is supported by the opinion of previous researchers, that there is still a general opinion that the quality of distance education is lower when compared to conventional classroom education [24]. Although it needs improvement, the use of distance learning in the future looks bright [17]. This learning underlines the need for a comprehensive and wise evolution of distance education if it is to become a model of future education [56].

\section{CONCLUSION}

Based on the results and discussion it can be concluded that online distance learning at the time of the COVID-19 pandemic was carried out in almost all regions of West Sumatra in accordance with government policy. The current learning implementation can be carried out because of the support of technological developments and most teachers already have the ability to use these technological devices. However, the implementation of this learning still has limitations so it is necessary for further improvement so that learning can be carried out better.

\section{ACKNOWLEDGMENTS}

Thank you to the teacher who has agreed to be a respondent in this study.

\section{REFERENCES}

[1] D. Stovall, "On Knowing: Willingness, fugitivity and abolition in precarious times," J. Lang. Lit. Educ., vol. 16, no. 1, pp. 1-7, 2020.

[2] X. Cheng, "Challenges of "School' s Out, But Class's On" to school education: Practical exploration of Chinese schools during the COVID-19 Pandemic," SIEF, vol. 5, no. 2, pp. 501516, 2020.

[3] UNICEF, Guidaance for COVID-19 prevention and control in sc, no. March. New York: United Nations Children's Fund (UNICEF), 2020.

[4] M. McAleer, "Prevention is better than the cure: Risk management of COVID-19," J. Risk Financ. Manag., vol. 13, no. 3, pp. 1-5, 2020 .

[5] C. Wang, Z. Cheng, and X. Yue, "Risk management of COVID-19 by Universities in China," J. Risk Financ. Manag., vol. 13, no. 2, pp. 1-6, 2020.

[6] J. Yao, J. Rao, T. Jiang, and C. Xiong, "What role should teachers play in online teaching during the COVID-19 Pandemic? Evidence from China," SIEF, vol. 5, no. 2, pp. $517-$ 524, 2020.

[7] R. S. Fadillah, "School from Home, harapan guru untuk orang 
tua dan anak," Kompasiana.com, 17-Apr-2020.

[8] D. Pancawati, "Suka duka belajar di rumah," https://bebas.kompas.id, 2020.

[9] G. K. Apeutung, "Pendidikan dalam kepungan virus corona," https://www.floresa.co/2020/04/03/pendidikan-dalamkepungan-virus-corona/, 03-Apr-2020.

[10] G. Suharwoto, "Pembelajaran online di tengah Pandemi Covid19, tantangan yang mendewasakan," timesindonesia.co.id, 02Apr-2020.

[11] L. Kusuma, "Cegah sebaran Covid-19 di satuan pendidikan, Kemendikbud gandeng swasta siapkan solusi belajar daring," www.kemendikbud.go.id, 2020.

[12] R. Setiawan, "Penerapan School From Home selama PSBB," www.rancah.com, 21-Apr-2020.

[13] M. Rajab, "Evaluasi dan optimalisasi pembelajaran daring," detikNews, Jakarta, 01-Apr-2020.

[14] L. Zhou and C. Li, "Can student self-directed learning improve their academic performance? Experimental evidence from the instruction of protocol-guided learning in China's elementary and middle schools," SIEF, vol. 5, no. 1, pp. 469-480, 2020.

[15] W. D. Chawinga and P. A. Zozie, "Increasing access to higher education through open and distance learning: Empirical findings from Mzuzu University, Malawi," Int. Rev. Res. Open Distrib. Learn., vol. 17, no. 4, pp. 1-20, 2016.

[16] B. L. Bower and K. P. Hardy, "From correspondence to cyberspace: Changes and challenges in distance education," New Dir. Community Coll., vol. 128, pp. 5-12, 2004.

[17] D. Vasilevska, B. Rivza, T. Pivac, V. Alekneviciene, and A. ParliÒska, "Analysis of the demand for distance education at eastern and central European higher education institutions," $J$. Teach. Educ. Sustain., vol. 19, no. 1, pp. 106-116, 2017.

[18] A. Kuruvilla, S. Norton, S. Chalasani, and M. Gee, "Best practices in initiating online programs at public institutions," Bus. Educ. Innov., vol. 4, no. 2, pp. 121-127, 2012

[19] S. K. Pangeni, "Open and distance learning: Cultural practice in Nepal," Eur. J. Open, Distance e-Learning -, vol. 19, no. 2, pp. 32-45, 2016.

[20] A. Poudel, "Open learning: A mode of delivering curricula," in Distance Education, 2006, pp. 106-116.

[21] W. K. Koomson, "Mobile learning: Application of whatsapp messenger as a learning tool in a university distance learning program in Ghana," in 15th International Conference on Cognition and Exploratory Learning in Digital Age (CELDA 2018), 2018, pp. 45-52.

[22] A. Bowser, K. Davis, J. Singleton, and T. Small, "Professional learning: A collaborative model for online teaching and development," SRATE J., vol. 26, no. 1, pp. 1-8, 2017.

[23] M. G. Kudryavtseva, "Possibilities of distance learning as a means of foreign language learning motivation among students of Economics," Procedia-Social Behav. Sci., vol. 152, pp. 1214-1218, 2014

[24] E. Demirel, "Accreditation of distance learning," Univers. J. Educ. Res., vol. 4, no. 10, pp. 2469-2476, 2016.

[25] M. Firat and H. Serpil, "Comparing the internet usage of preservice language teachers with teachers of other subjects: Distance learning vs . On-Campus learning," PROFILE, vol. 19, no. 1, pp. 55-72, 2017.

[26] J. Botha and M. Coetzee, "The influence of biographical factors on adult learner self-directedness in an open distance learning environment," Int. Rev. Res. Open Distrib. Learn., vol. 17, no. 4, pp. 242-263, 2016

[27] L. Scott and P. Temple, "A conceptual framework for building UDL in a special education distance education course," J. Educ.
Online, vol. 14, no. 1, 2017.

[28] C. W. Irwin and E. T. Stafford, Survey methods for educators : Collaborative survey development (part 1 of 3). Washington, DC: U.S: Department of Education, Institute of Education Sciences, National Center for Education Evaluation and Regional Assistance, Regional Educational Laboratory Northeast \& Islands, 2016

[29] A. M. Pazzaglia, E. T. Stafford, and S. M. Rodriguez, Survey methods for educators: Selecting samples and administering surveys (part 2 of 3). Washington, DC: U.S: Department of Education, Institute of Education Sciences, National Center for Education Evaluation and Regional Assistance, Regional Educational Laboratory Northeast \& Islands, 2016.

[30] J. Walston, J. Redford, and M. P. Bhatt, Workshop on survey methods in education research: facilitator's guide and resources. Washington, DC: U.S: Department of Education, Institute of Education Sciences, National Center for Education Evaluation and Regional Assistance, Regional Educational Laboratory Midwest, 2017.

[31] K. Kellen, A. Silva, and P. A. Behar, "Digital competence model of distance learning students," in 14th International Conference on Cognition and Exploratory Learning in Digital Age (CELDA 2017) DIGITAL, 2017, no. Celda, pp. 109-116.

[32] B. Warsita, Pendidikan jarak jauh. Bandung: Remaja Rosdakarya, 2011.

[33] M. Pradana and N. W. Amir, "Measuring e-learning effectiveness at Indonesian private," Int. J. Environ. Sci. Educ., vol. 11, no. 18, pp. 11541-11554, 2016.

[34] C. Amini and O. Oluyide, "Building capacity for open and distance learning (ODL) in west Africa Sub-region: The pivotal role of RETRIDAL," Open Prax., vol. 8, no. 4, pp. 337-350, 2016.

[35] H. Estelami, "The pedagogical and institutional impact of disruptive innovations in distance business education," Am. $J$ Bus. Educ., vol. 10, no. 3, pp. 97-108, 2017.

[36] D. E. Atkins, J. S. Brown, and A. L. Hammond, "A review of the open educational resources (OER) movement: Achievements, challenges, and new opportunities," 2007.

[37] T. Wilson, "New ways of mediating learning: Investigating the implications of adopting open educational resources for tertiary education at an institution in the United Kingdom as compared to one in South Africa," Int. Rev. Res. Open Distance, vol. 9 no. 1, pp. 1-19, 2008.

[38] D. Coetzee, "A centralised model for design , delivery and governance of open distance learning at dual mode universities," in BCES Conference Books, 2019, vol. 17, pp. 45-50.

[39] M. Kiscu and H. Arslan, "Virtual leadership at distance education teams," Turkish Online J. Distance Educ. July, vol. 17, no. 3, pp. 136-156, 2016

[40] Y. Hsu and Y. Ching, "A review of models and frameworks for designing mobile learning experiences and environments," Can J. Learn. Technol., vol. 41, no. 3, pp. 1-2, 2015.

[41] C. Kee and Z. Samsudin, "Mobile devices: toys or learning tools for the 21 century teenagers?," Tojet, vol. 13 , no. 3 , p. $107-122,2014$

[42] A. Lepp, J. E. Barkley, and A. C. Karpinski, "The relationship between cell phone use, academic performance, anxiety, and satisfaction with Life in college students," Comput. Human Behav., vol. 31, pp. 343-350, 2014

[43] M. Saran, G. Seferoğlu, and K. ve Cağgltay, "Mobile assisted language learning: English pronunciation at learners' fingertips," Eurasian J. Educ. Res., vol. 34, pp. 97-114, 2009.

[44] S. Ramadhan, Y. Asri, E. Sukma, and V. Indriyani, "Design of 
learning modules writing factual text based on discovery learning by using mobile devices," in Proceedings of the Third Workshop on Multidisiplinary and Its Application, WMA-3 2019, 2020.

[45] S. Ramadhan, V. Indriyani, Y. Asri, and E. Sukma, "Design of learning modules writing narrative text based on Project Based Learning (PjBL) by using mobile devices," in Journal of Physics: Conference Series, 2020, pp. 1-9.

[46] V. Indriyani and S. Ramadhan, "The development teaching of writing fable text module with project based learning (PjBL) containing characters," in Advances in Social Science, Education and Humanities Research, 2017, vol. 104, pp. 1621.

[47] Atmazaki and V. Indriyani, "Design of reading materials based on contextual teaching and learning (CTL)," in Advances in Social Science, Education and Humanities Research, 2019, vol. 301, pp. 235-241.

[48] S. Ramadhan, Y. Asri, and V. Indriyani, "Learning Module Design Writing Argumentative Text Based Problem-Based Learning," in Advances in Social Science, Education and Humanities Research, 2018, vol. 263, pp. 194-200.

[49] E. A. et al Willis, "Distance learning strategies for weight management utilizing social media: A comparison of phone conference call verses social media platform. Rational and design for a randomized study," Contemp. Clin. Trials, vol. 47, pp. 282-288, 2016.

[50] A. García-floriano, A. Ferreira-santiago, C. Yáñez-márquez, O. Camacho-nieto, M. Aldape Pérez, and Y. Villuendas-Rey, "Social web content enhancement in a distance learning environment: Intelligent metadata generation for resources," Int. Rev. Res. Open Distrib. Learn., vol. 18, no. 1, pp. 161-176, 2017.

[51] L. Harasim, Learning theory and online technology. New York: Routledge, 2012.

[52] E. Mnkandla and A. Minnaar, "The use of social media in elearning: A metasynthesis," Int. Rev. Res. Open Distrib. Learn., vol. 18, no. 5, pp. 227-248, 2017.

[53] Atmazaki and V. Indriyani, "Digital literacy competencies for teacher education students," in Advances in Social Science, Education and Humanities Research, 2019, vol. 335, pp. 10101018.

[54] S. Ramadhan, E. Sukma, and V. Indriyani, "Teacher competence in utilizing digital media literacy in education," in International Conference Computer Science and Engineering, 2019, pp. 1-5.

[55] S. Ramadhan, E. Sukma, and V. Indriyani, "Education and Digital Media Literacy: The Use of Digital Media by Teachers in Middle Schools," in ICCLE 2019, 2019.

[56] J. Graham, J. Haidt, and B. A. Nosek, "Liberals and conservatives rely on different sets of moral foundations," $J$. Pers. Soc. Psychol., vol. 96, no. 5, pp. 1029-1046, 2009. 